\title{
Autoregulatory CD8 T cells depend on cognate antigen recognition and CD4/CD 8 myelin determinants \\ OPEN
}

Sterling B. Ortega, $\mathrm{PhD}$ * Venkatesh P. Kashi,

$\mathrm{PhD}^{*}$

Khrishen Cunnusamy,

$\mathrm{PhD}$

Jorge Franco, BS

Nitin J. Karandikar, MD, $\mathrm{PhD}$

Correspondence to Dr. Karandikar: nitin-karandikar@uiowa.edu
Supplemental data at Neurology.org/nn

\section{ABSTRACT}

Objective: To determine the antigenic determinants and specific molecular requirements for the generation of autoregulatory neuroantigen-specific $\mathrm{CD}^{+} \mathrm{T}$ cells in models of multiple sclerosis (MS).

Methods: We have previously shown that MOG35-55-specific CD8 ${ }^{+} \mathrm{T}$ cells suppress experimental autoimmune encephalomyelitis (EAE) in the C57BL/6 model. In this study, we utilized multiple models of EAE to assess the ability to generate autoregulatory $C D 8^{+} T$ cells.

Results: We demonstrate that alternative myelin peptides (PLP178-191) and other susceptible mouse strains (SJL) generated myelin-specific CD8 ${ }^{+} T$ cells, which were fully capable of suppressing disease. The disease-ameliorating function of these cells was dependent on the specific cognate myelin antigen. Generation of these autoregulatory $\mathrm{CD} 8^{+} \mathrm{T}$ cells was not affected by thymic selection, but was dependent on the presence of both $\mathrm{CD}^{+}{ }^{+}$and $\mathrm{CD} 8^{+} \mathrm{T}$-cell epitopes in the immunizing encephalitogenic antigen.

Conclusions: These studies show that the generation of autoregulatory CD8 ${ }^{+} \mathrm{T}$ cells is a more generalized, antigen-specific phenomenon across multiple neuroantigens and mouse strains, with significant implications in understanding disease regulation. Neurol Neuroimmunol Neuroinflamm 2015;2:e170; doi: 10.1212/NXI.0000000000000170

\section{GLOSSARY}

CFA $=$ complete Freund's adjuvant; CFSE $=$ carboxyfluorescein succinimidyl ester; $\mathbf{E A E}=$ experimental autoimmune encephalomyelitis; $\mathbf{G A}=$ glatiramer acetate; $\mathbf{M H C}=$ major histocompatibility complex; $\mathbf{M O G}=$ myelin oligodendrocyte glycoprotein; $\mathbf{M S}=$ multiple sclerosis; $\mathbf{O V A}=$ ovalbumin; $\mathbf{P L P}=$ proteolipid protein; $\mathbf{T C R}=$ T-cell receptor; UTSW $=$ UT Southwestern; WT = wild-type.

Multiple sclerosis (MS) is a chronic immune-mediated demyelinating disorder of the CNS. Studies utilizing the experimental autoimmune encephalomyelitis (EAE) model of MS have established $\mathrm{T}$ cells to be major mediators of CNS pathology. Studies in human MS show that CD8 ${ }^{+} \mathrm{T}$ cells outnumber $\mathrm{CD}^{+} \mathrm{T}$ cells in MS lesions, produce inflammatory interleukin-17, and express cytotoxic markers like granzyme B. ${ }^{1-3}$ The antigenic specificity of these CNS-infiltrating cells is unclear. In EAE models, there are descriptions of pathogenic as well as disease-ameliorating $\mathrm{CD}^{+} \mathrm{T}$ cells. For example, myelin basic protein-specific $\mathrm{CD}^{+} \mathrm{T}$ cells in $\mathrm{C} 3 \mathrm{H}$ mice and myelin oligodendrocyte glycoprotein (MOG)-reactive CD8 ${ }^{+} \mathrm{T}$ cells in $\mathrm{B} 6$ mice have been shown to be pathogenic in certain settings. ${ }^{4-8}$ In contrast, $\beta 2$-microglobulin and CD8-deficient mice demonstrate more severe EAE, ${ }^{9-12}$ $\mathrm{CD}^{+} \mathrm{CD}^{-} 8^{-}$and $\mathrm{CD} 8^{+} \mathrm{CD} 122^{+}$cells modulate pathogenic $\mathrm{CD} 4^{+} \mathrm{T}$ cells, ${ }^{11,13}$ and there are robust descriptions of T-cell receptor (TCR)-specific and Qa-1-restricted ${ }^{14-16}$ non-CNS-specific disease-modulating $\mathrm{CD}^{+} \mathrm{T}$ cells.

In both MS and EAE, we have observed that neuroantigen-specific $\mathrm{CD}^{+} \mathrm{T}$ cells (CNSCD8) modulate encephalitogenic $\mathrm{CD}^{+} \mathrm{T}$ cells. ${ }^{12,17-20}$ Specifically, our EAE studies reveal a disease-regulatory function for CNS-CD8 ${ }^{+} \mathrm{T}$ cells, which is major histocompatibility complex

\footnotetext{
*These authors contributed equally to this work (co-first authors).

From the Departments of Pathology (S.B.O., V.P.K., K.C., J.F., N.J.K.) and Neurology and Neurotherapeutics (S.B.O., N.J.K.), UT Southwestern Medical Center, Dallas, TX; and the Department of Pathology (N.J.K.), University of Iowa, Iowa City.

Funding information and disclosures are provided at the end of the article. Go to Neurology.org/nn for full disclosure forms. The Article Processing Charge was paid by the authors.

This is an open access article distributed under the terms of the Creative Commons Attribution-NonCommercial-NoDerivatives License 4.0 (CC BY-NC-ND), which permits downloading and sharing the work provided it is properly cited. The work cannot be changed in any way or used commercially.
} 

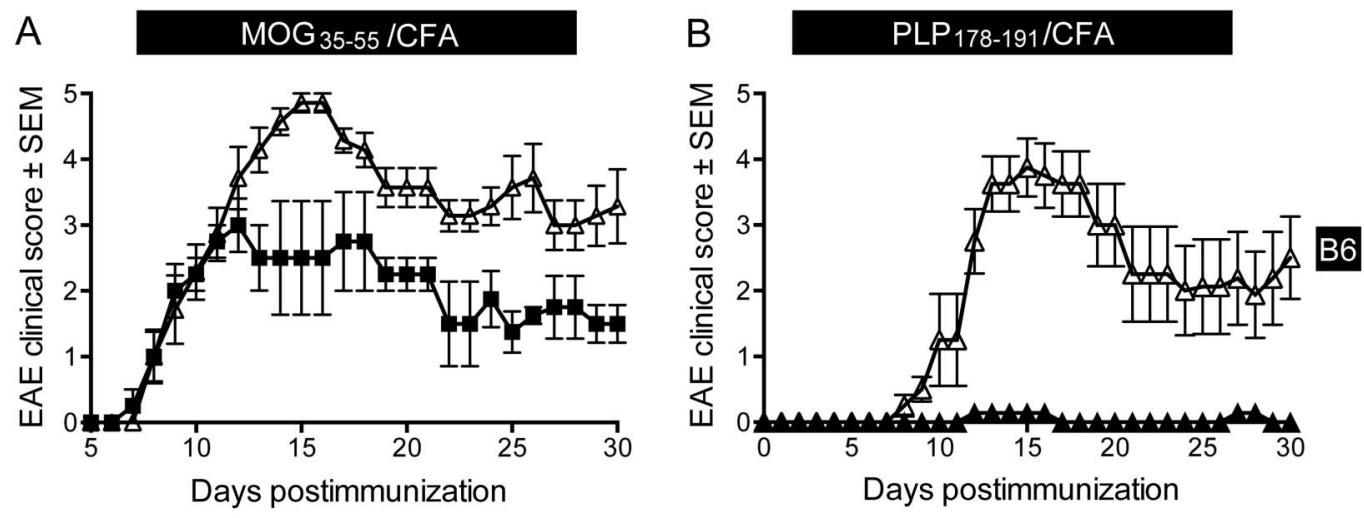

$$
\begin{aligned}
& * \pm \mathrm{OVA}_{323-339}-\mathrm{CD} 8 \\
& \pm \mathrm{MOG}_{35-55}-\mathrm{CD} 8
\end{aligned}
$$$$
\begin{aligned}
& * \\
& \star \text { OVA }_{323-339}-\mathrm{CD} 8 \\
& \star \mathrm{PLP}_{178-191}-\mathrm{CD} 8
\end{aligned}
$$
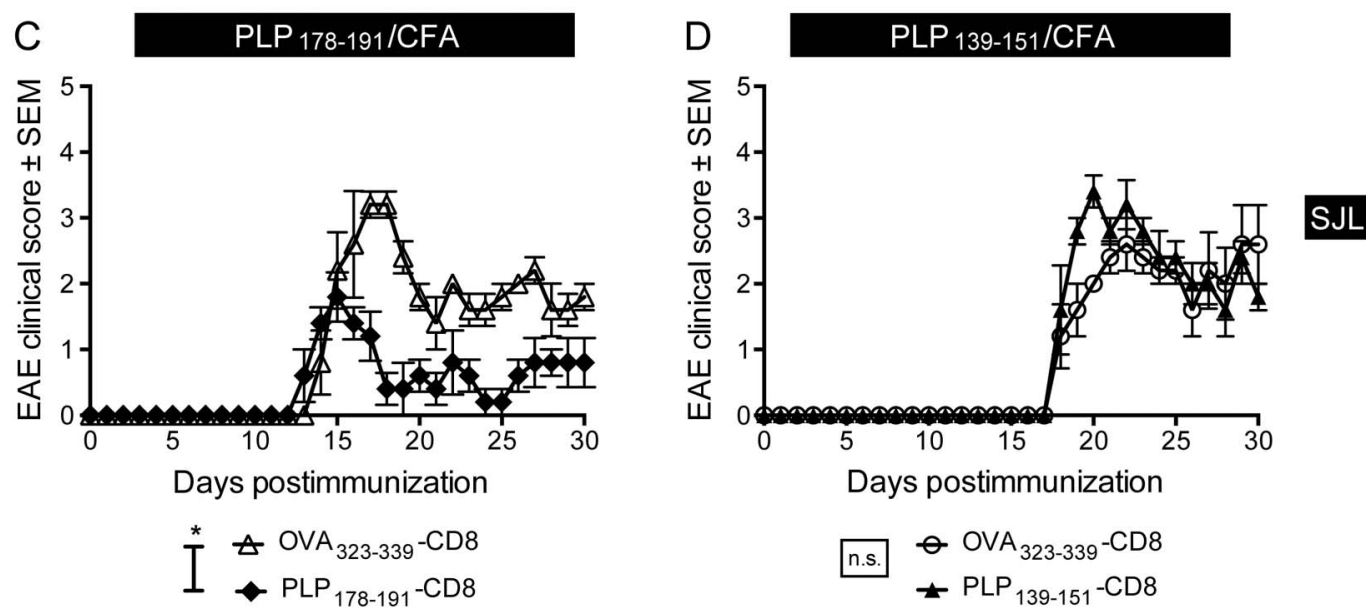

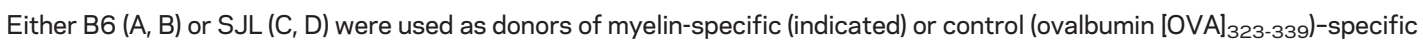
$\mathrm{CD}^{+} \mathrm{T}$ cells, which were adoptively transferred IV into naive mice (same strains) on day 1 . On day 0 , experimental autoimmune encephalomyelitis (EAE) was induced in all mice by immunization with the appropriate cognate antigens in complete Freund's adjuvant (CFA) (A: $100 \mu \mathrm{g}$ of myelin oligodendrocyte glycoprotein $[\mathrm{MOG}]_{35-55}$; B and C: $100 \mu \mathrm{g}$ of proteolipid protein $[P L P]_{178-191}$; and D: $100 \mu \mathrm{g}$ of $\left.\mathrm{PLP}_{139-151}\right)$. Graphs represent mean clinical scores \pm SEM. Data are representative of 3-5 independent experiments, 7-10 mice per condition per experiment. $* p<0.05$. n.s. $=$ not significant.

(MHC) Class I restricted, requires interferon- $\gamma$ and perforin, and modulates antigen-presenting cells and $\mathrm{CD}^{+} \mathrm{T}$ cells. These studies were performed predominantly in the $\mathrm{B} 6$ model of EAE induced by $\mathrm{MOG}_{35-55}$ antigen. Moreover, the antigenic requirements of these interactions and the conditions needed to generate autoregulatory CNS-CD8 ${ }^{+}$T-cell responses have not been elucidated and this is the focus of the current report.

METHODS Mice. All mouse protocols were approved by the UT Southwestern (UTSW) Medical Center Institutional Animal Care and Use Committee. Mice were housed in the UTSW Animal Resource Center. Wild-type (WT) C57BL/6 (B6) mice were purchased from Taconic (Hudson, NY) and UTSW Breeding Core. SJL/J (SJL) mice were purchased from the NCI Mouse Repository (Frederick, MD). MOG-deficient mice ${ }^{21}$ were a gift from Dr. Eric Huseby.
Active EAE induction and evaluation. $\mathrm{MOG}_{35-55}$ (MEVGWYRSPFSRVVHLYRNGK), proteolipid protein (PLP) ${ }_{178-191}$ (NTWTTCQSIAFPSK), PLP ${ }_{139-151}$ (HSLGKWLGHPDKF), $\mathrm{MOG}_{37-46}, \mathrm{MOG}_{40-49}, \mathrm{MOG}_{44-54}, \mathrm{MOG}_{37-50}$, and ovalbumin $(\mathrm{OVA})_{323-339}$ (ISQAVHAAHAEINEAGR) were synthesized by UTSW Chemistry Technology Center. EAE was induced as described previously. ${ }^{12,20}$ Briefly, female mice were immunized with $100 \mu \mathrm{g}$ of antigens/complete Freund's adjuvant (CFA), followed by $250 \mathrm{ng}$ of pertussis toxin IP on days 0 and 2, except the PLP 139-151-induced model. EAE severity was assessed in a blinded manner on a 0 to 5 scale.

Adoptive transfer of antigen-specific $\mathrm{CD8}^{+} \mathbf{T}$ cells. Naive mice were immunized with $100 \mu \mathrm{g}$ of antigen. At day 20, lymph node cells and splenocytes were harvested and stimulated with cognate antigen and rmIL-2 $(10 \mathrm{pg} / \mathrm{mL})$ for 72 hours. Highly enriched $\mathrm{CD}^{+} \mathrm{T}$ cells (purity $\sim 95 \%$ ) were obtained using anti-CD8 Miltenyi microbeads; $5 \times 10^{6}$ cells were injected IV. After 24 hours, primary EAE was induced.

CFSE-based proliferation. Antigen-specific responses were evaluated using the carboxyfluorescein succinimidyl ester 
Figure 2 In vivo requirement of cognate antigen for autoreactive $\mathrm{CD} 8^{+} \mathrm{T}$-cell disease regulation

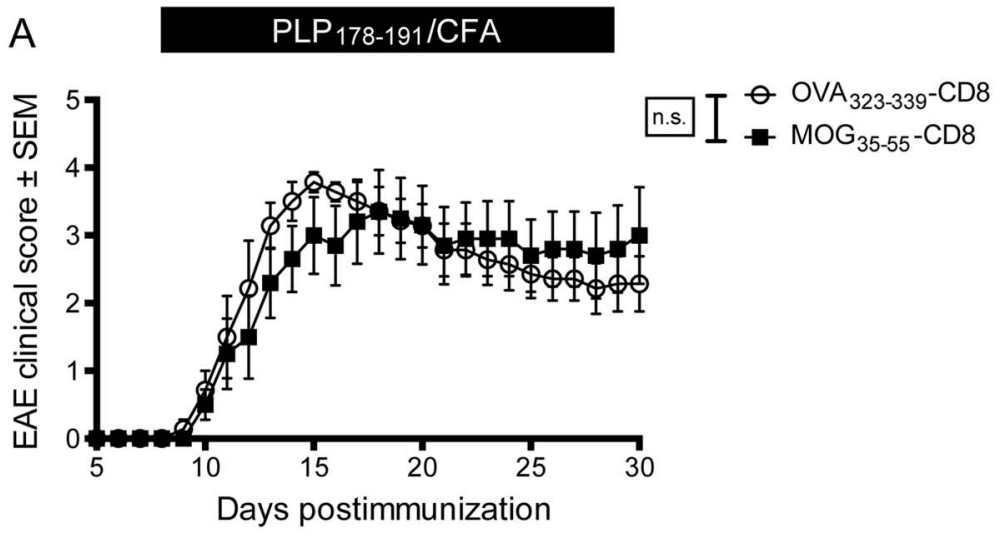

B $\mathrm{MOG}_{35-55 / C F A}$

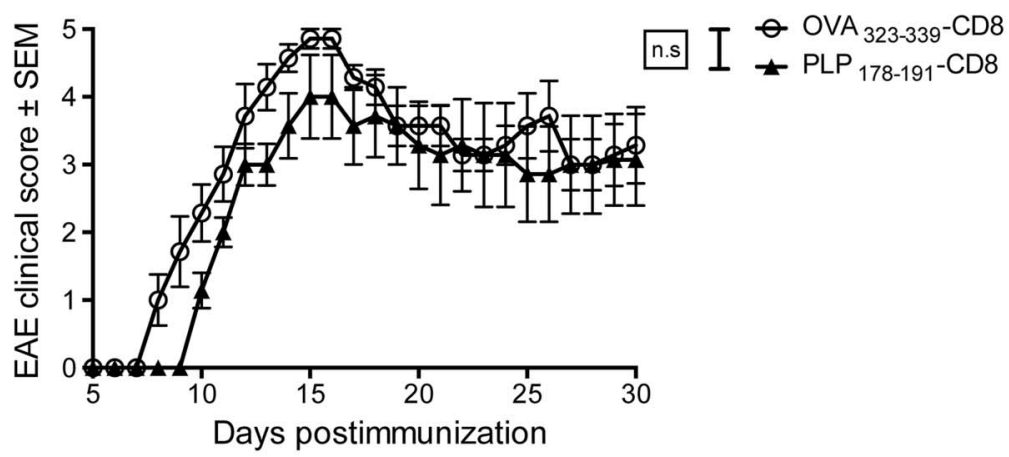

\section{MOG $_{35-55}+$ PLP $_{178-191} / \mathrm{CFA}$}

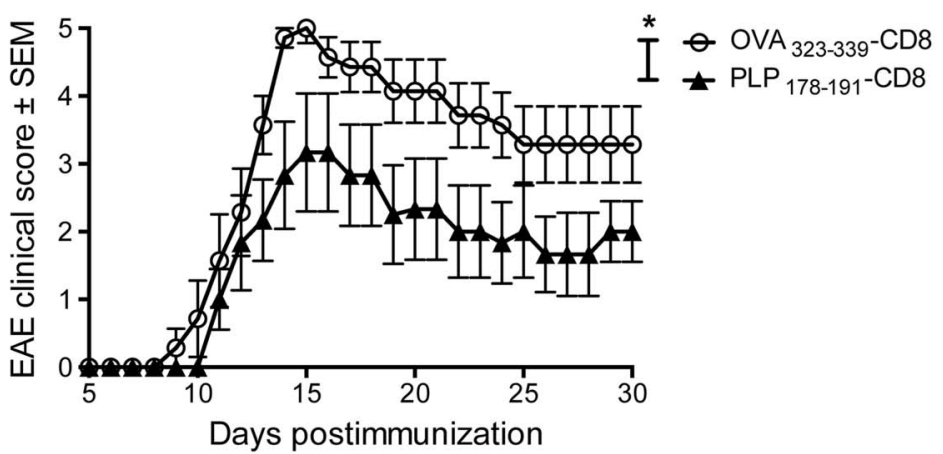

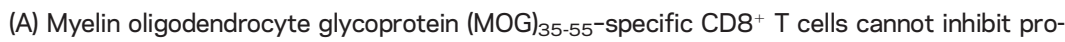
teolipid protein (PLP) ${ }_{178-191}$ experimental autoimmune encephalomyelitis (EAE). MOG ${ }_{35-55^{-}}$

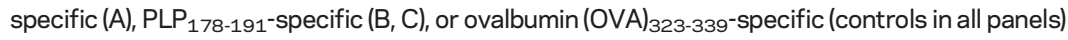
$\mathrm{CD}^{+} \mathrm{T}$ cells were transferred into naive $\mathrm{B} 6$ mice at day 1 . On day $0, \mathrm{EAE}$ was induced by immunization with $\mathrm{PLP}_{178-191}(\mathrm{~A}), \mathrm{MOG}_{35-55}(\mathrm{~B})$, and a combination of both $\mathrm{PLP}_{178-191}$ and $\mathrm{MOG}_{35-55}$ (C). Representative of 2 independent experiments each. $* p<0.05$. CFA $=$ complete Freund's adjuvant; n.s. $=$ not significant.

(CFSE)-based proliferation assay as described. ${ }^{12,20}$ Cells were activated with cognate antigen at $20 \mu \mathrm{g} / \mathrm{mL}$ for 5 days, washed, incubated with FcR blocking reagent, stained for CD8/CD4/ TCR $\beta$, and fixed in paraformaldehyde, followed by acquisition of flow data.

Statistics. Statistical analyses between groups (2-tailed Student $t$ tests) were performed using GraphPad (La Jolla, CA) Prism 5.0c. A $p$ value $\leq 0.05$ was considered statistically significant.
RESULTS Disease-ameliorating ability of various myelin-specific $\mathrm{CD8}^{+} \mathbf{T}$ cells in EAE. We have previously shown that myelin-specific $\mathrm{CD}^{+}$T-cell responses (myelin-CD8) are generated in multiple EAE models. ${ }^{20}$ However, we have predominantly utilized the $\mathrm{MOG}_{35-55}$-induced model of EAE in B6 mice to dissect the regulatory role of these cells. ${ }^{12,19,20}$ In this study, we asked whether this phenomenon of myelin-CD8-mediated downregulation of EAE was more generalized. First, we confirmed our prior findings that immunization with $\mathrm{MOG}_{35-55}$ in $\mathrm{B} 6$, PLP $_{178-191}$ in $\mathrm{B} 6$ and SJL, and PLP ${ }_{139-151}$ in SJL mice resulted in appropriate $\mathrm{EAE}$ disease (figure e-1A at Neurology.org/nn), with induction of robust $\mathrm{CD}^{+}$ $\mathrm{T}$-cell responses (figure e-1B).

We next asked if myelin-CD8 plays a pathogenic/ regulatory role in EAE. Similar to our previous reports, ${ }^{12,20}$ myelin-CD8 obtained from donor mice (figure e-2) was transferred to naive mice (day -1 ), followed by EAE induction with the corresponding cognate antigen (day 0). Similar to disease amelioration by $\mathrm{MOG}_{35-55}-\mathrm{CD}^{+} \mathrm{T}$ cells (figure $1 \mathrm{~A}$ ), ${ }^{12,19}$ PLP $_{178-191-C D 8}$ were capable of suppressing $\mathrm{PLP}_{178-191}$-induced EAE in $\mathrm{B} 6$ mice (figure $1 \mathrm{~B}$ ). Additionally, PLP $178-191-\mathrm{CD} 8$ also suppressed $\mathrm{PLP}_{178-191}$-induced EAE in SJL (figure 1C). Interest-

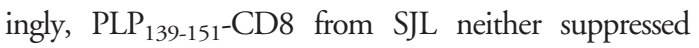
nor exacerbated PLP 139 -151-induced EAE (figure 1D).

Cognate antigen presentation is required for the regulatory function of $\mathrm{CD8}^{+} \mathbf{T}$ cells. We observed that $\mathrm{CD}^{+}$ $\mathrm{T}$ cells with 2 separate antigenic specificities (MOG $_{35-55}$ and PLP $_{178-191}$ ) from the same strain of mouse (B6) had the ability to downregulate disease (figure 1, A and B). This gave us the tools to address antigenic specificity of this regulation. We asked whether $\mathrm{MOG}_{35-55}$-specific $\mathrm{CD}^{+}{ }^{+} \mathrm{T}$ cells were capable of suppressing PLP 178 -191-induced EAE (and vice versa). $\mathrm{PLP}_{178-191}, \mathrm{MOG}_{35-55}$, or $\mathrm{OVA}_{323-339-\text { specific }} \mathrm{CD}^{+}$ $\mathrm{T}$ cells were generated and transferred on day -1 . On day 0 , EAE was induced using noncognate encephalitogenic peptide antigen $\left(\mathrm{PLP}_{178-191} / \mathrm{CFA}\right.$ in case of $\mathrm{MOG}_{35-55}-\mathrm{CD} 8$ [figure $2 \mathrm{~A}$ ] and $\mathrm{MOG}_{35-55} / \mathrm{CFA}$ in case of PLP-CD8 [figure 2B]). We observed that $\mathrm{MOG}_{35-55-\mathrm{CD}^{+}}{ }^{\mathrm{T}} \mathrm{T}$ cells were unable to protect mice from PLP 178 -191-induced EAE disease (figure $2 \mathrm{~A}$ ). Similarly, PLP $178-191^{-s p e c i f i c ~ C D 8 ~ T ~ c e l l s ~ w e r e ~ u n a b l e ~}$ to modulate $\mathrm{MOG}_{35-55}$-induced $\mathrm{EAE}$ (figure $2 \mathrm{~B}$ ). This was despite the ability of the same cells (in the same experiments) to regulate disease induced by their corresponding cognate antigens (figure 1). Interestingly,

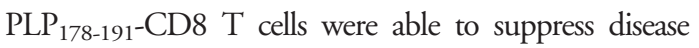
symptoms when EAE was induced by $\mathrm{MOG}_{35-55} /$ $\mathrm{PLP}_{178-191}$ coimmunization (figure 2C). These data reveal that autoregulatory neuroantigen-specific $\mathrm{CD}^{+}$ 
A

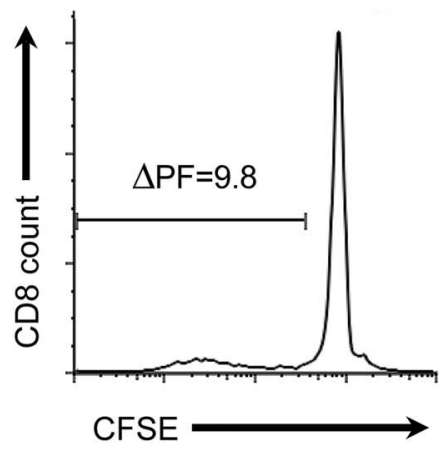

B

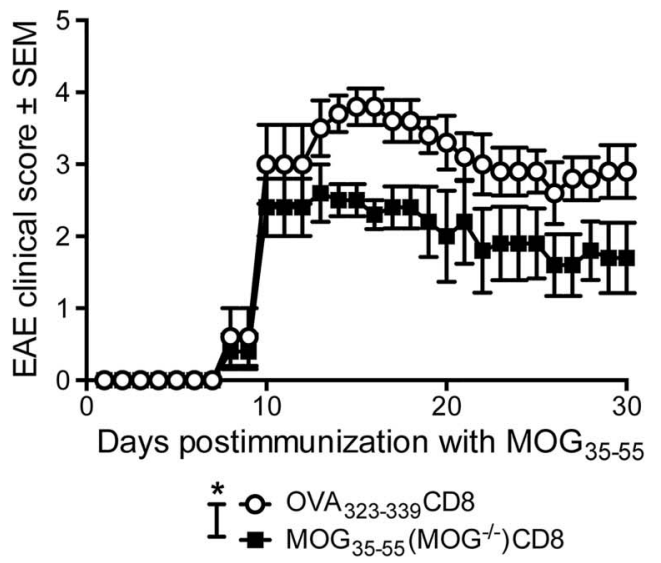

(A) Following the immunization of myelin oligodendrocyte glycoprotein (MOG) ${ }^{-1-}$ B6 mice with $\mathrm{MOG}_{35-55}$, lymph node cells and splenocytes were harvested and carboxyfluorescein succinimidyl ester (CFSE) stained. Cells where then cultured in vitro with $\mathrm{MOG}_{35-55}$ and 5 days later CFSE dilution measured. $\triangle$ Proliferating fraction (PF) is the $\%$ of CFSE low CD8 ${ }^{+}$ $T$ cells in the $\mathrm{MOG}_{35-55}$ stimulated condition minus the no antigen (background) condition. Data are representative of 3 independent experiments. (B) MOG-CD8 ${ }^{+} \mathrm{T}$ cells generated from $\mathrm{MOG}^{-1-}$ mice were injected IV into naive B6 mice and experimental autoimmune encephalomyelitis (EAE) was induced with $\mathrm{MOG}_{35-55} /$ complete Freund's adjuvant (CFA) immunization on day 0 . Representative data of 2 experiments are shown, $n=5-7$ per condition. $* p<0.05$.

$\mathrm{T}$ cells are dependent on cognate antigen presentation during in vivo disease suppression.

Generation of autoregulatory $\mathrm{CD8}^{+} \mathrm{T}$ cells is not dependent on central tolerance but requires presence of $\mathrm{CD}^{+}$and $\mathrm{CD8}^{+}$determinants in immunizing antigen. Next, we wanted to determine the antigenic requirements for the generation of autoregulatory $\mathrm{CD}^{+} \mathrm{T}$ cells. In human MS, we have previously observed that foreign antigen$\mathrm{CD}^{+} \mathrm{T}$ cells lack immunosuppressive ability. ${ }^{17}$ In this study, we observed a difference between disease regulatory ability of $\mathrm{MOG}_{35-55}$ and $\mathrm{PLP}_{178-191^{-}} \mathrm{CD}^{+}$cells (both autoregulatory in nature) vs that of PLP $_{139-151}$ (figure 1). We hypothesized that this difference could relate to thymic presentation of certain epitopes (such as $\mathrm{MOG}_{35-55}$ and PLP $\mathrm{P}_{178-191}$ in mice and other autoantigens in humans) and lack of presentation of specific epitopes (such as PLP $139-151$ ), ${ }^{22}$ leading to qualitatively different responses. We therefore investigated whether central tolerance might play a role in autoregulatory $\mathrm{CD}^{+}$T-cell generation by utilizing $\mathrm{MOG}^{-/-} \mathrm{B} 6$ mice

\section{Table 1 Truncated MOG peptides}

$\begin{array}{lll}\begin{array}{l}\text { Truncated peptide } \\ \mathrm{MOG}_{35-55}\end{array} & \begin{array}{l}\text { Sequence } \\ \text { MEVGWYRSPFSRVVHLYRNGK }\end{array} & \begin{array}{l}\text { Described epitope } \\ \mathrm{CD} 8_{1} \text { and } \mathrm{CD} 8_{2} \text { and CD4 } \\ \text { (parent peptide) }\end{array} \\ \mathrm{MOG}_{37-46} & \text { MEVGWYRSPFSRVVHLYRNGK } & \mathrm{CD} 8_{1} \\ \mathrm{MOG}_{44-54} & \text { MEVGWYRSPFSRVVHLYRNGK } & \mathrm{CD} 8_{2} \\ \mathrm{MOG}_{40-49} & \text { MEVGWYRSPFSRVVHLYRNGK } & \mathrm{CD} 4 \\ \mathrm{MOG}_{37-50} & \text { MEVGWYRSPFSRVVHLYRNGK } & \mathrm{CD} 8_{1} \& \mathrm{CD} 4\end{array}$

Abbreviation: MOG = myelin oligodendrocyte glycoprotein for this purpose (with the notion that these mice would not have central tolerance to MOG). We immunized these mice with $\mathrm{MOG}_{35-55}$ peptide and used them as donors of $\mathrm{CD}^{+} \mathrm{T}$ cells. Parallel CFSE assays confirmed the presence of $\mathrm{MOG}_{35-55}$-specific $\mathrm{CD}^{+}$T-cell responses in these mice (figure $3 \mathrm{~A}$ ). Activated $\mathrm{CD} 8^{+} \mathrm{T}$ cells derived from such cultures were transferred to naive WT B6 recipient mice at day -1 , followed by induction of $\mathrm{EAE}$ on day 0 . As shown in figure $3 \mathrm{~B}, \mathrm{MOG}_{35-55^{-}}$ $\mathrm{CD}^{+} \mathrm{T}$ cells derived from $\mathrm{MOG}^{-1-}$ mice showed the ability to suppress EAE, similar to those from WT mice (figure 1A). Thus, lack of central tolerance to MOG did not affect the disease-ameliorating ability of myelin-CD8 $T$ cells in this model.

In these experiments, $\mathrm{MOG}_{35-55}$ peptide generated both pathogenic $\mathrm{CD}^{+}{ }^{+} \mathrm{T}$-cell responses and regulatory $\mathrm{CD}^{+} \mathrm{T}$-cell responses. Within the $\mathrm{MOG}_{35-55}$ peptide, there are 2 previously characterized CD8 epitopes: $\mathrm{MOG}_{37-46^{6}}$ and $\mathrm{MOG}_{44-54}{ }^{23}$ and one CD4 epitope: $\mathrm{MOG}_{40-49}{ }^{24}$ Using this information, we wanted to determine what portion of the $\mathrm{MOG}_{35-55}$ molecule was required to generate the disease-ameliorating myelin-specific $\mathrm{CD}^{+} \mathrm{T}$ cells. First, we immunized mice with several truncated peptides (table 1) and determined whether there was an antigen-specific $\mathrm{CD}^{+}$ T-cell response and if the generated $\mathrm{CD}^{+} \mathrm{T}$ cells were capable of ameliorating $\mathrm{MOG}_{35-55}$-induced EAE.

Although $\mathrm{MOG}_{37-46}$ and $\mathrm{MOG}_{44-54}$ immunizations did not induce EAE, robust CD8 responses were observed (figures 4, A and B, and e-3). Adoptive transfer of $\mathrm{CD}^{+} \mathrm{T}$ cells specific to these epitopes, however, failed to suppress $\mathrm{MOG}_{35-55}$-induced EAE (figures $4 \mathrm{C}$ 


\section{$\mathrm{MOG}_{37-46}\left(\mathrm{CD}_{1}\right.$-epitope $)$}

A

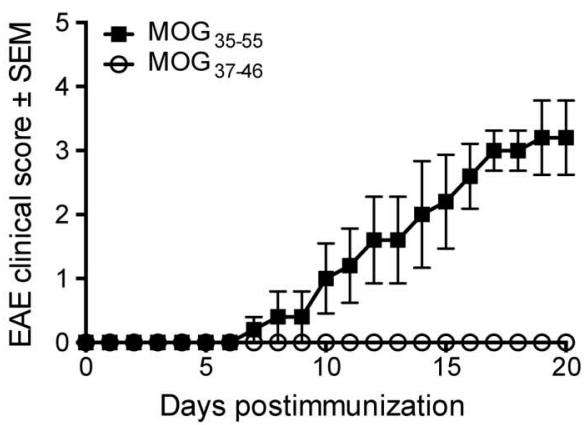

B

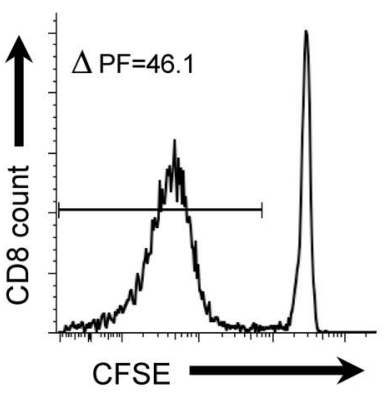

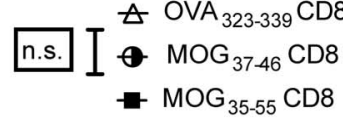

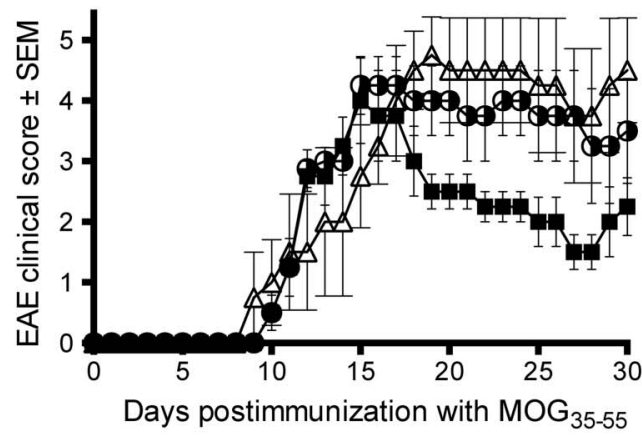

$\mathrm{MOG}_{40-49}(\mathrm{CD} 4-\mathrm{epitope})$

E

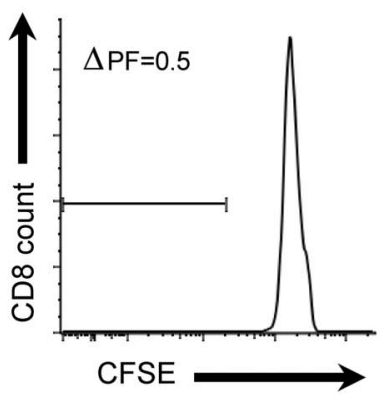

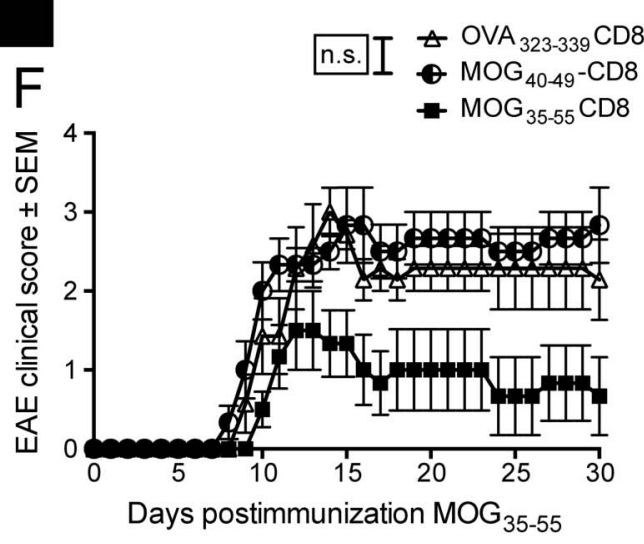

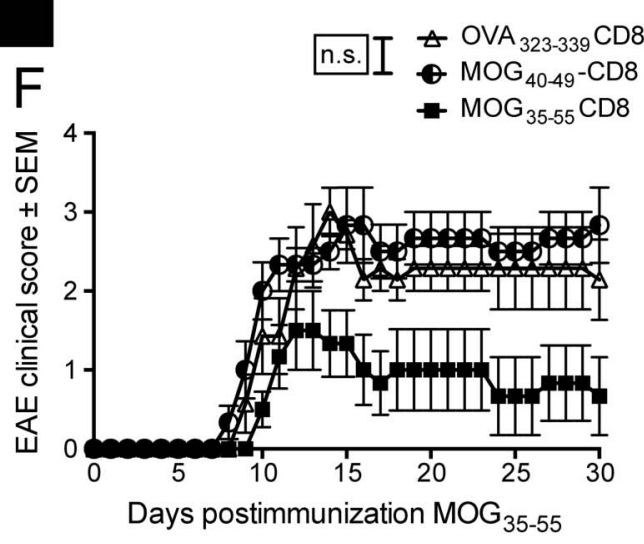

Days postimmunization

$\mathrm{MOG}_{37-50}(\mathrm{CD} 8-\mathrm{epitope}$ and CD4-epitope)

$\therefore \mathrm{OVA}_{323-339} \mathrm{CD} 8$

$\mathrm{H}$

- $\mathrm{MOG}_{37-50}-\mathrm{CD} 8$

G
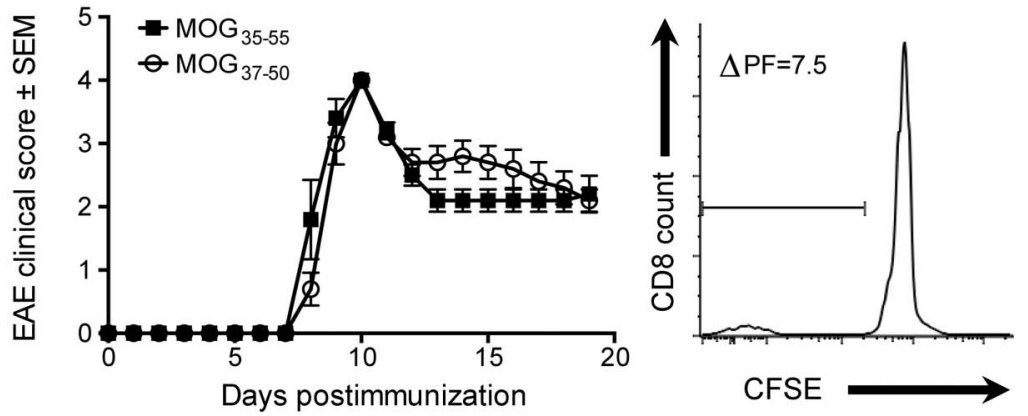

$\rightarrow \mathrm{MOG}_{35-55} \mathrm{CD} 8$

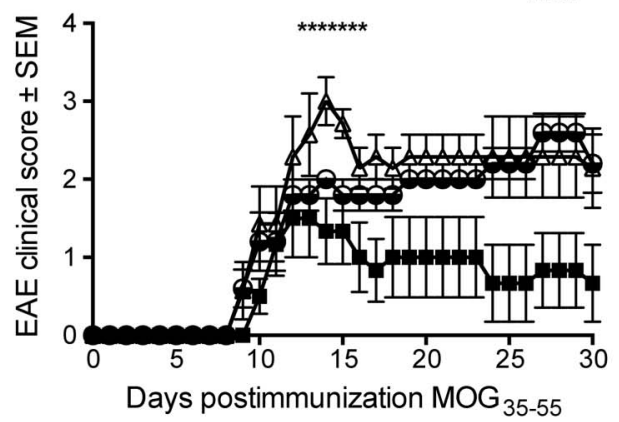

Naive B6 mice were immunized with $100 \mu \mathrm{g}$ of myelin oligodendrocyte glycoprotein (MOG) $35-55$ or indicated peptides and disease was monitored for 20 days (A, D, G). CD8 ${ }^{+}$T-cell responses were assayed to the indicated peptides using carboxyfluorescein succinimidyl ester (CFSE) dilution assays (B, E, H). Post in vitro activated donor $\mathrm{CD} 8^{+} \mathrm{T}$ cells specific to indicated peptides were transferred to naive mice, followed by induction of experimental autoimmune encephalomyelitis (EAE) using $\mathrm{MOG}_{35-55}$ in complete Freund's adjuvant (C, F, I). Data are representative of 3-5 independent experiments each, 7-10 mice per condition per experiment. $\triangle \mathrm{PF}=\Delta$ proliferating fraction; n.s. = not significant; OVA = ovalbumin.

and e-3). We next immunized a separate group of mice with the $\mathrm{CD}^{+}$T-cell epitope $\mathrm{MOG}_{40-49}$, which resulted in robust disease similar to $\mathrm{MOG}_{35-55}$ immunization (figure 4D) with an absence of any $\mathrm{CD}^{+} \mathrm{T}$-cell response (figure 4E). Expectedly, transfer of these cultured $\mathrm{CD}^{+} \mathrm{T}$ cells (likely representing naive and nonspecific $\mathrm{CD}^{+} \mathrm{T}$ cells) did not result in any disease modulation (figure $4 \mathrm{~F}$ ). Next, to test if immunization with both the CD8 epitopes contained within $M_{35-55}$ might be required to induce a fully functional regulatory $\mathrm{CD}^{+}{ }^{+} \mathrm{T}$-cell population, we generated $\mathrm{CD} 8^{+} \mathrm{T}$ cells by coimmunizing donor $\mathrm{B} 6$ mice with $\mathrm{MOG}_{44-54}$ and $\mathrm{MOG}_{37-46}$. Again, while $\mathrm{MOG}_{35-55}$-induced $\mathrm{CD}^{+} \mathrm{T}$ cells 
suppressed disease, $\left(\mathrm{MOG}_{37-46}+\mathrm{MOG}_{44-54}\right)$-induced $\mathrm{CD}^{+} \mathrm{T}$ cells failed to modulate EAE (figure e-4).

We finally hypothesized that immunization with an encephalitogenic CD4 T-cell epitope along with a CD8 T-cell epitope may be important to generate autoregulatory MOG-CD8 $\mathrm{T}$ cells. To test this, we immunized mice with $\mathrm{MOG}_{37-50}$, which encompasses a CD4 and a CD8 epitope. MOG $_{37-50}$ immunization resulted in primary EAE disease similar to $\mathrm{MOG}_{35-55}$ (figure 4G) and a CD8 response (figure $4 \mathrm{H}$ ). Transfer of $\mathrm{MOG}_{37-50}$-induced $\mathrm{CD}^{+} \mathrm{T}$ cells resulted in partial protection from EAE (figure 4I) that was not as robust as protection using $\mathrm{MOG}_{35-55}-\mathrm{CD} 8$ (peptide containing 2 CD8 and one CD4 determinant). Collectively, these data suggest that generation of autoregulatory $\mathrm{CD}^{+} \mathrm{T}$ cells requires the presence of the encephalitogenic CD4 epitope and at least one CD8 epitope in the $\mathrm{MOG}_{35-55}$-EAE model (table 2).

DISCUSSION Our understanding of autoreactive $\mathrm{T}$ cells is undergoing a paradigm shift. Until recently, cells capable of responding to self were viewed as effectors of pathology and this was understandable in light of the many endogenous central and peripheral mechanisms involved in tolerance induction. However, there is ample evidence that CNS-specific T-cell autoreactivity does not always equate to pathology and may, in fact, provide essential functions during health and serve a neuroprotective role in various settings, ${ }^{25-27}$ a concept labeled as protective autoimmunity.

There are several lines of evidence demonstrating the presence of autoantigen-specific immunoregulatory (autoregulatory) $\mathrm{CD}^{+} \mathrm{T}$ cells (reviewed in reference 28). In several reports by others and us, autoregulatory $\mathrm{CD}^{+} \mathrm{T}$ cells have been described in various human autoimmune diseases and models. ${ }^{29-34}$ In human MS, we have demonstrated the clinical relevance of this autoregulatory function that resides in the terminally differentiated subset, ${ }^{18}$ is significantly deficient during an acute relapse of disease, but recovers during the quiescent stage of MS. ${ }^{17}$ In addition, we have shown that myelin-specific $\mathrm{CD}^{+} \mathrm{T}$ cells modulate both active and adoptive EAE, ${ }^{12,20}$ by targeting encephalitogenic $\mathrm{CD} 4^{+}$

\begin{tabular}{|ccccc|}
\hline Table 2 & \multicolumn{4}{l}{ Antigen response and disease suppression of autoreactive CD8 ${ }^{+}$T cells } \\
Epitope & CD4 response & CD8 response & Primary EAE & Disease suppression \\
$\mathrm{MOG}_{35-55}$ & + & + & ++ & ++ \\
$\mathrm{MOG}_{37-46}$ & - & + & - & - \\
$\mathrm{MOG}_{44-54}$ & - & + & - & - \\
$\mathrm{MOG}_{40-49}$ & + & - & ++ & - \\
$\mathrm{MOG}_{37-50}$ & + & $+l-$ & ++ & $+/-$ \\
\hline
\end{tabular}

Abbreviations: $\mathrm{EAE}$ = experimental autoimmune encephalomyelitis; $\mathrm{MOG}=$ myelin oligodendrocyte glycoprotein.
T cells ${ }^{12}$ and modulating dendritic cell function. ${ }^{19}$ Since our prior EAE studies predominantly focused on the $\mathrm{MOG}_{35-55}$-induced EAE model in $\mathrm{B} 6$ mice, we wanted to determine the finer antigenic specificity of CD8-mediated regulation, the generalizability of this observation, and the antigenic requirements for the generation of this regulatory response.

We examined 4 EAE models from 2 mouse strains, and observed that 3 of 4 conditions resulted in the generation of autoregulatory $\mathrm{CD}^{+} \mathrm{T}$ cells. PLP $_{178-191}$-CD8 from both B6 and SJL mice were capable of suppressing EAE induced by the specific cognate antigen. Interestingly, PLP $139-151-\mathrm{CD} 8$ neither suppressed nor worsened cognate antigen-induced EAE. Thus, while we did not find evidence of a pathogenic role for these cells, these data also suggest that autoregulatory function may not be inherent to all CNS-CD8 ${ }^{+} \mathrm{T}$ cells. The nature of the difference between autoantigenspecific nonregulatory vs autoregulatory $\mathrm{CD} 8^{+} \mathrm{T}$ cells is unclear at this point. Overall, the magnitude of $\mathrm{CD}^{+}$ T-cell responses to various autoantigens was comparable across the models, with no statistically significant differences over multiple experiments. It is plausible that the pool of $\mathrm{PLP}_{139-151}-\mathrm{CD}^{+} \mathrm{T}$ cells may be functionally different. One explanation may be the lack of pertussis in the PLP $139-151$-induced EAE model, although this is not borne out in preliminary studies (not shown). We have also observed in other experiments that CNSspecific autoregulatory $\mathrm{CD}^{+} \mathrm{T}$ cells are induced in systems devoid of pertussis (unpublished observations, 2015). Also, $\mathrm{CD}^{+} \mathrm{T}$ cells generated to $\mathrm{MOG}_{37-46}$, $\mathrm{MOG}_{40-49}$, and $\mathrm{MOG}_{44-54}$ with pertussis failed to suppress EAE. Therefore, pertussis does not completely explain these functional differences and future studies focused on the detailed evaluation of various functional aspects of these nonregulatory autoreactive $\mathrm{CD}^{+} \mathrm{T}$ cells are essential.

We have previously shown that, in humans, myelin antigen-specific $\mathrm{CD}^{+} \mathrm{T}$ cells exhibit an autoregulatory function, whereas foreign antigen-specific $\mathrm{CD}^{+} \mathrm{T}$ cells do not show consistent suppressive potential. ${ }^{17}$ We hypothesized that this may be based on thymic selection, where only the low avidity autoantigen-specific $\mathrm{T}$ cells would escape negative selection. ${ }^{35}$ Interestingly, in mice, PLP expression in the thymus is restricted to the DM20 splice variant, ${ }^{22}$ which does not include the $\mathrm{PLP}_{139-151}$ region. This may potentially explain the differences between the $\mathrm{CD}^{+} \mathrm{T}$-cell populations. To address this hypothesis, we utilized $\mathrm{MOG}^{-1-}$ mice as donors of $\mathrm{MOG}_{35-55^{-}}$ $\mathrm{CD}^{+} \mathrm{T}$ cells (figure 3). These mice have higher avidity MOG-specific CD8 ${ }^{+} \mathrm{T}$ cells ${ }^{36}$ and an expansion of both $\mathrm{CD}^{+}{ }^{+}$and $\mathrm{CD}^{+} \mathrm{T}$ cells in response to MOG immunization. Again, we did not see any evidence of CD8-mediated pathogenicity using

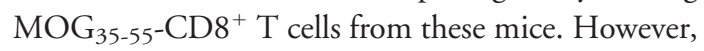


neither did we observe any significant deficiency in their ability to protect from EAE, suggesting that lack of thymic selection did not affect the regulatory repertoire in the MOG/B6 model.

As mentioned above, we found that $\mathrm{PLP}_{178-191^{-}}$ CD8 T cells were suppressive in nature. Most of the well-characterized immunosuppressive $\mathrm{CD}^{+}{ }^{+} \mathrm{T}$-cell populations, where antigenic specificity has been dissected, are targeted against antigens expressed on pathogenic $\mathrm{CD}^{+} \mathrm{T}$ cells, such as Qa-1-restricted heat shock proteins or fragments of TCR sequences. ${ }^{15,37,38}$ In these settings, suppressor $\mathrm{CD}^{+} \mathrm{T}$ cells raised against one autoreactive $\mathrm{CD}^{+} \mathrm{T}$ cell can, in turn, target other autoreactive $\mathrm{CD}^{+}{ }^{+} \mathrm{T}$ cells that express the same TCR or heat shock proteins. We have also described regulatory $\mathrm{CD}^{+}$T-cell responses, induced in mice and patients with MS following treatment with glatiramer acetate (GA), which appear to be MHC Class Ib restricted and are capable of functioning in vivo without the need for additional GA administration. ${ }^{39,40}$ In contrast to these situations, the regulatory populations of MOG-and PLP-induced $\mathrm{CD}^{+} \mathrm{T}$ cells appear to be specific to the CNS target antigens. To address this issue in greater detail, we took advantage of our observation that 2 different specificities of CNS-CD8 were disease suppressive in B6 mice. Thus, we asked whether PLP $178-191-\mathrm{CD} 8$ could suppress $\mathrm{MOG}_{35-55}$-induced disease and vice versa. These experiments revealed that $\mathrm{MOG}_{35-55}-\mathrm{CD} 8$ could not

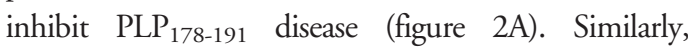
$\mathrm{PLP}_{178-191}$-CD8 could not suppress $\mathrm{MOG}_{35-55}$ disease (figure 2B). These findings support 2 important interpretations: (1) the $\mathrm{CD}^{+} \mathrm{T}$ cells derived from these cultures do not contain significant populations of cells targeted against non-CNS antigens expressed generally on autoreactive $\mathrm{CD}^{+}{ }^{+} \mathrm{T}$ cells (such as heat shock proteins or TCR peptides), and (2) the presence of their cognate antigens is required in vivo for their disease suppressive effects. The latter is also corroborated by our prior observations that CNS-CD8 $\mathrm{T}$ cells require in vivo MHC Class $\mathrm{I}^{12}$ and that they do not modulate dendritic cells in mice that do not receive cognate antigens. ${ }^{19}$ Moreover, PLP-CD8 significantly suppressed disease symptoms when EAE was induced by coimmunization with $\mathrm{MOG}_{35-55}$ and PLP-178-191, further indicating that immunization with cognate antigen supported their disease-ameliorating role. In the coimmunization setting, it is unclear whether PLP-CD8 only affected the PLP-CD4 response or were able to have an antigen nonspecific effect on MOG-CD4 response (e.g., through antigen-presenting cell modulation). This dissection will require future studies and will be important for the clinical context where multiple CNS specificities are involved.

In the final set of experiments, we dissected the fine specificity of MOG-CD8 and delineated the immunization requirements for generating MOGspecific suppressor $\mathrm{CD}^{+} \mathrm{T}$ cells. The encephalitogenic $\mathrm{MOG}_{35-55}$ sequence has been shown to contain one CD4 determinant $\left(\mathrm{MOG}_{40-49}\right)^{24}$ and 2 CD8 determinants $\left(\mathrm{MOG}_{37-46}\right.$ and $\left.\mathrm{MOG}_{44-54}\right),{ }^{6,23}$ as outlined in table 1 . We utilized these peptides to assess their encephalitogenicity and ability to induce suppressor $\mathrm{CD}^{+}$ $\mathrm{T}$ cells. As expected, the CD4 determinant induced EAE, but did not induce any regulatory $\mathrm{CD} 8^{+} \mathrm{T}$-cell responses (figure 4, D-F). The $\mathrm{CD}^{+}{ }^{+} \mathrm{T}$-cell epitopes, either individually or in combination, showed good induction of $\mathrm{CD}^{+}{ }^{+} \mathrm{T}$-cell responses, but no induction of EAE (figure 4, A and B, and not shown). This is in contrast to previous studies showing pathogenicity of MOG-induced $\mathrm{CD}^{+} \mathrm{T}$ cells ${ }^{6,8,23}$; however, this corroborates findings from us and others, showing no EAE induction using $\mathrm{MOG}_{35-55}$-induced $\mathrm{CD}^{+} \mathrm{T}$ cells. ${ }^{12,19,20}$ In keeping with this observation, $\mathrm{CD} 8^{+} \mathrm{T}$ cells induced by immunization with individual CD8 epitopes could not transfer EAE to naive mice and did not worsen $\mathrm{EAE}$ induced by $\mathrm{MOG}_{35-55}$ immunization, providing no evidence of their pathogenic role. Thus, at least in our hands, we have been unable to demonstrate pathogenic function for any of these MOG- or PLPspecific $\mathrm{CD}^{+} \mathrm{T}$ cells in the $\mathrm{B} 6$ or SJL systems.

Interestingly, $\mathrm{CD}^{+} \mathrm{T}$ cells induced by either $\mathrm{MOG}_{37-46}$ or MOG $44-54$ were also not capable of suppressing EAE, in contrast to $\mathrm{MOG}_{35-55}$-induced $\mathrm{CD}^{+}$ T cells. We asked whether this lack of suppressive activity could simply be a result of not having representation of CD8 responses to both of the CD8 determinants within the $\mathrm{MOG}_{35-55}$ peptide sequence. We therefore obtained $\mathrm{CD}^{+} \mathrm{T}$ cells from mice immunized with both CD8 epitopes. However, these CD8 responses were incapable of suppressing EAE (figure e-4). We thus hypothesized that it may be important to have a concomitant CD4 response to induce fully functional suppressor $\mathrm{CD}^{+} \mathrm{T}$ cells and addressed this hypothesis by utilizing the $\mathrm{MOG}_{37-50}$ peptide, containing one CD4 and one CD8 epitope. $\mathrm{MOG}_{37-50}$-derived $\mathrm{CD}^{+} \mathrm{T}$ cells were partially suppressive and decreased the severity of the acute phase of the disease, but did not replicate the full suppressive ability exhibited by $\mathrm{MOG}_{35-55}$-derived CD8 cells. An obvious reason might be the lack of CD8 responses to the other $\mathrm{CD} 8$ epitope. It is also possible that the full $\mathrm{MOG}_{35-55}$ sequence contains other CD8 epitopes that have not been characterized thus far or are represented by lower avidity responses that are important in the overall suppressive ability. There may also exist specific functional deficits in the $\mathrm{MOG}_{37-50}$-derived $\mathrm{CD}^{+} \mathrm{T}$ cells, compared to the complete complement, and these would need to be dissected through future studies. Overall, these findings suggest that generation of autoregulatory $\mathrm{CD}^{+} \mathrm{T}$ cells is dependent on the combination of CD4 and CD8 epitopes available and the context in which these responses are induced. 
Taken together, in this study we provide evidence of the presence of myelin-specific regulatory $\mathrm{CD}^{+} \mathrm{T}$ cells across different models of EAE. These cells require interaction with their cognate antigen in vivo for suppressive functionality and their generation is dependent on the availability of CD4 and CD8 specificities. These findings significantly augment our understanding of autoregulatory $\mathrm{CD}^{+}$T-cell biology and have important implications in harnessing these cells to develop immunotherapeutic approaches for MS and other immunemediated diseases.

\section{AUTHOR CONTRIBUTIONS}

S.B.O. designed and performed experiments, analyzed data, and wrote the manuscript. V.P.K. designed and performed experiments, analyzed data, and cowrote the manuscript. K.C. and J.F. performed some of the experiments and critically evaluated the manuscript. N.J.K. designed and supervised the study and cowrote the manuscript.

\section{ACKNOWLEDGMENT}

The authors thank Thomas Lee and Wallace Baldwin for technical assistance; and Ibrahim Noorbhai, Katie Poinsatte, and Drs. Ethan Baughman, Todd Eagar, Mihail Firan, Sushmita Sinha, and Ann M. Stowe for discussions and critical reading of this manuscript.

\section{STUDY FUNDING}

These studies were supported, in part, by grants (to N.J.K.) from the NIH and the National Multiple Sclerosis Society.

\section{DISCLOSURE}

S. Ortega reports no disclosures. V. Kashi is an associate editor for Journal of Human Virology \& Retrovirology. K. Cunnusamy and J. Franco report no disclosures. N.J. Karandikar received research support from NIH/NIAD and National Multiple Sclerosis Society. Go to Neurology.org/nn for full disclosures.

Received April 17, 2015. Accepted in final form September 10, 2015.

\section{REFERENCES}

1. Babbe H, Roers A, Waisman A, et al. Clonal expansions of CD8(+) $\mathrm{T}$ cells dominate the $\mathrm{T}$ cell infiltrate in active multiple sclerosis lesions as shown by micromanipulation and single cell polymerase chain reaction. J Exp Med 2000; 192:393-404.

2. Hauser SL, Bhan AK, Gilles F, Kemp M, Kerr C, Weiner HL. Immunohistochemical analysis of the cellular infiltrate in multiple sclerosis lesions. Ann Neurol 1986;19:578-587.

3. Neumann H, Medana IM, Bauer J, Lassmann H. Cytotoxic $\mathrm{T}$ lymphocytes in autoimmune and degenerative CNS diseases. Trends Neurosci 2002;25:313-319.

4. Huber M, Heink S, Pagenstecher A, et al. IL-17A secretion by CD8 + T cells supports Th17-mediated autoimmune encephalomyelitis. J Clin Invest 2013;123:247-260.

5. Huseby ES, Liggitt D, Brabb T, Schnabel B, Ohlen C, Goverman J. A pathogenic role for myelin-specific CD8 $(+) \mathrm{T}$ cells in a model for multiple sclerosis. J Exp Med 2001;194:669-676.

6. Ford ML, Evavold BD. Specificity, magnitude, and kinetics of MOG-specific CD8 + T cell responses during experimental autoimmune encephalomyelitis. Eur J Immunol 2005;35:76-85.

7. Anderson AC, Chandwaskar R, Lee DH, et al. A transgenic model of central nervous system autoimmunity mediated by CD4+ and CD8+ T and B cells. J Immunol 2012;188: 2084-2092.
8. Bettini M, Rosenthal K, Evavold BD. Pathogenic MOGreactive $\mathrm{CD} 8+\mathrm{T}$ cells require MOG-reactive $\mathrm{CD} 4+$ $\mathrm{T}$ cells for sustained CNS inflammation during chronic EAE. J Neuroimmunol 2009;213:60-68.

9. Linker RA, Rott E, Hofstetter HH, Hanke T, Toyka KV, Gold R. EAE in beta-2 microglobulin-deficient mice: axonal damage is not dependent on MHC-I restricted immune responses. Neurobiol Dis 2005;19:218-228.

10. Koh DR, Fung-Leung WP, Ho A, Gray D, Acha-Orbea H, Mak TW. Less mortality but more relapses in experimental allergic encephalomyelitis in CD8-/- mice. Science 1992;256: 1210-1213.

11. Najafian N, Chitnis T, Salama AD, et al. Regulatory functions of CD8+CD28- $\mathrm{T}$ cells in an autoimmune disease model. J Clin Invest 2003;112:1037-1048.

12. Ortega SB, Kashi VP, Tyler AF, Cunnusamy K, Mendoza JP, Karandikar NJ. The disease-ameliorating function of autoregulatory CD8 T cells is mediated by targeting of encephalitogenic CD4 T cells in experimental autoimmune encephalomyelitis. J Immunol 2013;191:117-126.

13. Lee YH, Ishida Y, Rifa'i M, Shi Z, Isobe K, Suzuki H. Essential role of $\mathrm{CD} 8+\mathrm{CD} 122+$ regulatory $\mathrm{T}$ cells in the recovery from experimental autoimmune encephalomyelitis. J Immunol 2008;180:825-832.

14. Kumar V. Homeostatic control of immunity by TCR peptide-specific Tregs. J Clin Invest 2004;114:1222-1226.

15. Panoutsakopoulou V, Huster KM, McCarty N, et al. Suppression of autoimmune disease after vaccination with autoreactive $\mathrm{T}$ cells that express $\mathrm{Qa}-1$ peptide complexes. J Clin Invest 2004;113:1218-1224.

16. Varthaman A, Clement M, Khallou-Laschet J, et al. Physiological induction of regulatory Qa-1-restricted CD8+ $\mathrm{T}$ cells triggered by endogenous CD $4+\mathrm{T}$ cell responses. PLoS One 2011;6:e21628.

17. Baughman EJ, Mendoza JP, Ortega SB, et al. Neuroantigenspecific CD8+ regulatory T-cell function is deficient during acute exacerbation of multiple sclerosis. J Autoimmun 2011; 36:115-124.

18. Cunnusamy K, Baughman EJ, Franco J, et al. Disease exacerbation of multiple sclerosis is characterized by loss of terminally differentiated autoregulatory CD8 $+\mathrm{T}$ cells. Clin Immunol 2014;152:115-126.

19. Kashi VP, Ortega SB, Karandikar NJ. Neuroantigen-specific autoregulatory CD8 $+\mathrm{T}$ cells inhibit autoimmune demyelination through modulation of dendritic cell function. PLoS One 2014;9:e105763.

20. York NR, Mendoza JP, Ortega SB, et al. Immune regulatory CNS-reactive CD8+T cells in experimental autoimmune encephalomyelitis. J Autoimmun 2010;35:33-44.

21. Delarasse C, Daubas P, Mars LT, et al. Myelin/oligodendrocyte glycoprotein-deficient (MOG-deficient) mice reveal lack of immune tolerance to MOG in wild-type mice. J Clin Invest 2003;112:544-553.

22. Klein L, Klugmann M, Nave KA, Tuohy VK, Kyewski B. Shaping of the autoreactive $\mathrm{T}$-cell repertoire by a splice variant of self protein expressed in thymic epithelial cells. Nat Med 2000;6:56-61.

23. Sun D, Whitaker JN, Huang Z, et al. Myelin antigen-specific CD8 + T cells are encephalitogenic and produce severe disease in C57BL/6 mice. J Immunol 2001;166:7579-7587.

24. Mendel Kerlero de Rosbo N, Ben-Nun A. Delineation of the minimal encephalitogenic epitope within the immunodominant region of myelin oligodendrocyte glycoprotein: diverse $\mathrm{V}$ beta gene usage by $\mathrm{T}$ cells recognizing the core epitope 
encephalitogenic for $\mathrm{T}$ cell receptor $\mathrm{V}$ beta $\mathrm{b}$ and $\mathrm{T}$ cell receptor V beta a H-2b mice. Eur J Immunol 1996;26:2470-2479.

25. Hauben E, Agranov E, Gothilf A, et al. Posttraumatic therapeutic vaccination with modified myelin self-antigen prevents complete paralysis while avoiding autoimmune disease. J Clin Invest 2001;108:591-599.

26. Moalem G, Leibowitz-Amit R, Yoles E, Mor F, Cohen IR, Schwartz M. Autoimmune T cells protect neurons from secondary degeneration after central nervous system axotomy. Nat Med 1999;5:49-55.

27. Kipnis J, Gadani S, Derecki NC. Pro-cognitive properties of T cells. Nat Rev Immunol 2012;12:663-669.

28. Sinha S, Itani FR, Karandikar NJ. Immune regulation of multiple sclerosis by CD8 + T cells. Immunol Res 2014; 59:254-265.

29. Dinesh RK, Skaggs BJ, La Cava A, Hahn BH, Singh RP. $\mathrm{CD} 8+$ tregs in lupus, autoimmunity, and beyond. Autoimmun Rev 2010;9:560-568.

30. Filaci G, Fenoglio D, Indiveri F. CD8(+) T regulatory/ suppressor cells and their relationships with autoreactivity and autoimmunity. Autoimmunity 2011;44:51-57.

31. Tsai S, Shameli A, Yamanouchi J, et al. Reversal of autoimmunity by boosting memory-like autoregulatory $\mathrm{T}$ cells. Immunity 2010;32:568-580.

32. Davila E, Kang YM, Park YW, et al. Cell-based immunotherapy with suppressor CD8 $+\mathrm{T}$ cells in rheumatoid arthritis. J Immunol 2005;174:7292-7301.

33. Gravano DM, Hoyer KK. Promotion and prevention of autoimmune disease by $\mathrm{CD} 8+\mathrm{T}$ cells. J Autoimmun 2013;45:68-79.
34. Jiang H, Canfield SM, Gallagher MP, et al. HLA-E-restricted regulatory $\mathrm{CD} 8(+) \mathrm{T}$ cells are involved in development and control of human autoimmune type 1 diabetes. J Clin Invest 2010;120:3641-3650.

35. Anderson AC, Nicholson LB, Legge KL, Turchin V, Zaghouani H, Kuchroo VK. High frequency of autoreactive myelin proteolipid protein-specific $\mathrm{T}$ cells in the periphery of naive mice: mechanisms of selection of the self-reactive repertoire. J Exp Med 2000;191:761-770.

36. Leech MD, Carrillo-Vico A, Liblau RS, Anderton SM. Recognition of a high affinity MHC class I-restricted epitope of myelin oligodendrocyte glycoprotein by CD8(+) $\mathrm{T}$ cells derived from autoantigen-deficient mice. Front Immunol 2011;2:17.

37. Jiang H, Kashleva H, Xu LX, et al. T cell vaccination induces T cell receptor Vbeta-specific Qa-1- restricted regulatory CD8 (+) T cells. Proc Natl Acad Sci U S A 1998;95:4533-4537.

38. Zang YC, Hong J, Rivera VM, Killian J, Zhang JZ. Human anti-idiotypic $\mathrm{T}$ cells induced by TCR peptides corresponding to a common CDR3 sequence motif in myelin basic proteinreactive T cells. Int Immunol 2003;15:1073-1080.

39. Tennakoon DK, Mehta RS, Ortega SB, Bhoj V, Racke MK, Karandikar NJ. Therapeutic induction of regulatory, cytotoxic CD8 + T cells in multiple sclerosis. J Immunol 2006;176: 7119-7129.

40. Tyler AF, Mendoza JP, Firan M, Karandikar NJ. CD8 T Cells are required for glatiramer acetate Therapy in autoimmune demyelinating disease. PLoS One 2013;8:e66772. 


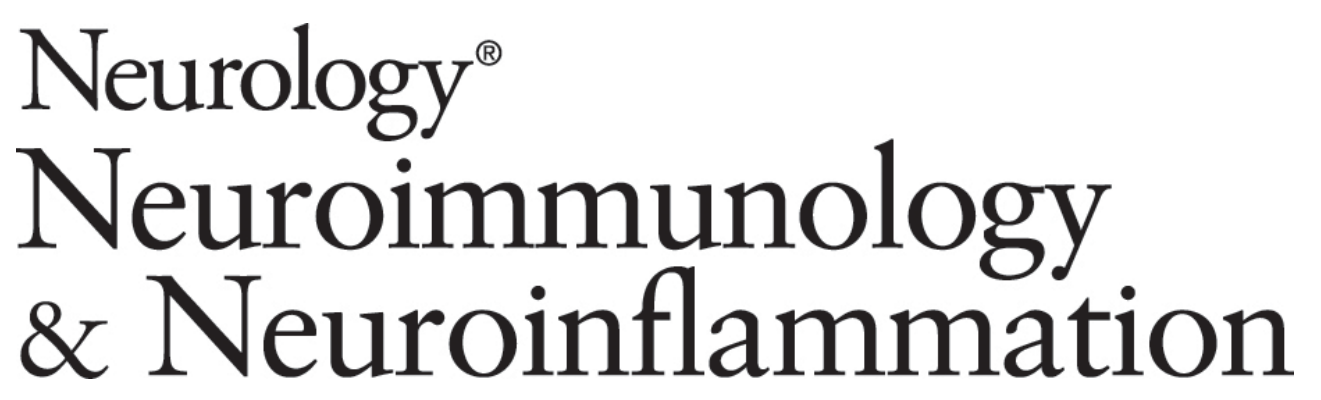

Autoregulatory CD8 $\mathrm{T}$ cells depend on cognate antigen recognition and CD4/CD8 myelin determinants

Sterling B. Ortega, Venkatesh P. Kashi, Khrishen Cunnusamy, et al.

Neurol Neuroimmunol Neuroinflamm 2015;2;

DOI 10.1212/NXI.0000000000000170

This information is current as of November 4, 2015

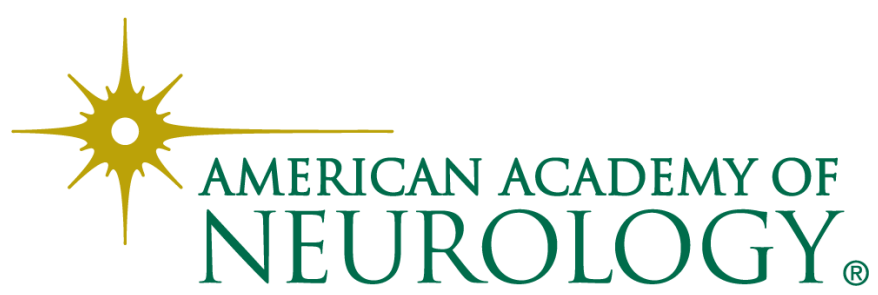




\section{Updated Information \& Services}

\section{Supplementary Material}

\section{References}

Citations

Subspecialty Collections

Permissions \& Licensing

Reprints including high resolution figures, can be found at: http://nn.neurology.org/content/2/6/e170.full.html

Supplementary material can be found at: http://nn.neurology.org/content/suppl/2015/11/04/2.6.e170.DC1

This article cites 40 articles, 11 of which you can access for free at: http://nn.neurology.org/content/2/6/e170.full.html\#\#ref-list-1

This article has been cited by 5 HighWire-hosted articles: http://nn.neurology.org/content/2/6/e170.full.html\#\#otherarticles

This article, along with others on similar topics, appears in the following collection(s):

\section{All Immunology}

http://nn.neurology.org//cgi/collection/all_immunology

Autoimmune diseases

http://nn.neurology.org//cgi/collection/autoimmune_diseases

Multiple sclerosis

http://nn.neurology.org//cgi/collection/multiple_sclerosis

Information about reproducing this article in parts (figures,tables) or in its entirety can be found online at:

http://nn.neurology.org/misc/about.xhtml\#permissions

Information about ordering reprints can be found online: http://nn.neurology.org/misc/addir.xhtml\#reprintsus

Neurol Neuroimmunol Neuroinflamm is an official journal of the American Academy of Neurology.

Published since April 2014, it is an open-access, online-only, continuous publication journal. Copyright $\odot$ 2015 American Academy of Neurology. All rights reserved. Online ISSN: 2332-7812.

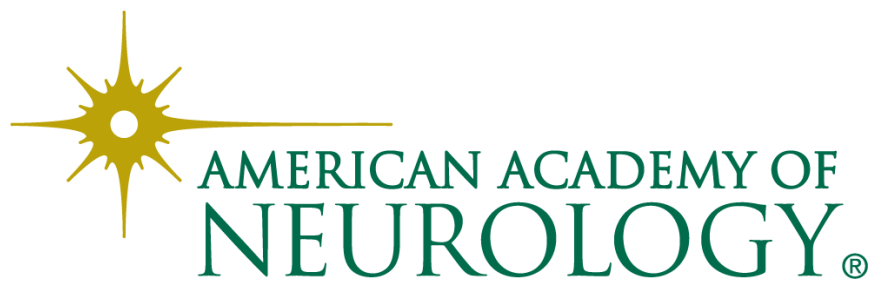

